\section{International Scientific Journal Theoretical \& Applied Science}

p-ISSN: 2308-4944 (print) e-ISSN: 2409-0085 (online)

Year: 2017 Issue: $04 \quad$ Volume: 48

Published: $30.04 .2017 \quad$ http://T-Science.org

SECTION 11. Biology. Ecology. Veterinary.
Nodira Xanxodjayeva

Associate Professor, Candidate of Biological Sciences,

Tashkent State Pedagogical University named after Nizami

Surayyo Mutalovna Ermatova Associate Professor, Candidate of Biological Sciences, Tashkent State Pedagogical University named after Nizami

Umida Dilmurodovna Muradova Teacher,

Tashkent State Pedagogical University named after Nizami

Jasur Samandarovich Sadinov

Teacher

Tashkent State Pedagogical University named after Nizami

\title{
ANTHROPOGENIC IMPACT OF CHEMICALS ON SOIL
}

Abstract: The article reveals the goals and tasks of ecology, as a complex scientific discipline. It poses one of its main problems - anthropogenic impact on the Earth's soil cover. The author reveals the problem of chemical soil contamination, gives materials on soil cover monitoring, gives examples of methods for determining pollution, gives examples of insane use of soil resources and offers practical steps aimed at understanding the importance of the student's task in protecting the Earth.

Key words: ecology, soil, Earth's soil cover, anthropogenic.

Language: Russian

Citation: Xanxodjayeva N, Ermatova SM, Muradova UD, Sadinov JS (2017) ANTHROPOGENIC IMPACT OF CHEMICALS ON SOIL. ISJ Theoretical \& Applied Science, 04 (48): 216-219.

Soi: http://s-o-i.org/1.1/TAS-04-48-35 Doi: crossef https://dx.doi.org/10.15863/TAS.2017.04.48.35

\section{АНТРОПОГЕННОЕ ВЛИЯНИЕ ХИМИЧЕСКИХ ВЕЩЕСТВ НА ПОЧВУ}

Аннотация: В статье раскрываются иели и задачи «экологии» как комплексной научной дисциилины. Ставится одна из основных её проблем - антропогенное влияние на почвенный покров Земли. Авторы раскрывают проблемы химического загрязнения почвы, приводит материаль по мониторингу почвенного покрова, приводит примеры методов определения загрязнения, описывает последствия бездумного использования почвенных ресурсов и предлагает практические шаги, направленные на осознание студентами важности стоящих перед ними задач по охране земли.

Ключевые слова: экология, почва, почвенный покров Земли, антропогенная.

\section{Introduction}

Проблема экологической безопасности и охраны окружающей среды - одна из важнейших проблем современности. Как отмечал первый президент Республики Узбекистан И. А. Каримов, «экологическая проблема актуальна во всех странах и регионах мира, во всех уголках Земного шара, различна лишь степень её остроты». В нашем регионе сложилась одна из опаснейших зон экологического бедствия, где «практически все сферы обитания и жизнедеятельности человека в регионе подвержены экологическому риску».

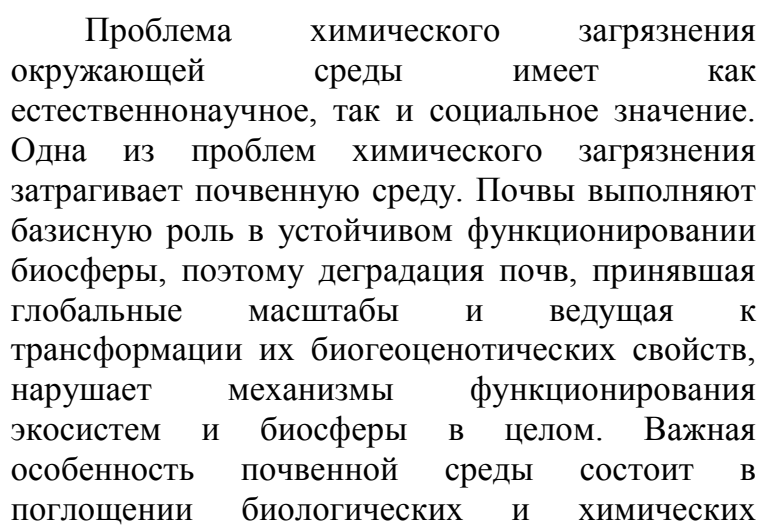


загрязнителей, то есть почва является природным сорбентом.

\section{Materials and Methods}

Почва состоит из минеральных, органических и органо-минеральных комплексов, соединений, почвенных растворов, воздуха, почвенных микроорганизмов, насекомых, животных и загрязнителей. Для гигиенической оценки почвы важно знать ее естественный химический состав. Минеральные вещества составляют 60-80\% - это кремнозем, кварц, алюмосиликаты. Особый интерес имеется к микроэлементам - F, J, Mn, Se - их повышенное или пониженное содержание влияет на формирование естественных геохимических провинций с их эндемическими заболеваниями (флюороз, кариес, эндемический зоб). Причиной химического загрязнения почв может быть не только антропогенная деятельность человека, но и природные условия местности. В некоторых районах Земли естественное содержание отдельных элементов и их соединений в почвах и водах существенно превышает фоновые значения и обычно приурочено к залежам полезных ископаемых или зонам вулканизма. А.П. Виноградов назвал такое явление биогеохимической провинцией.

Органические вещества представлены в почве органическими кислотами (гуминовыми и др.), веществами, синтезированными почвенными микроорганизмами, называемыми гумусом, и чужеродными для почвы веществами, поступающими извне.

Растет загрязнение почв пестицидами, которое отрицательно влияет на живое население почвы, поддерживающее её плодородие. Пестициды вызывают депрессию процесса нитрификации, увеличивают эрозию почв, влияют на насекомых-опылителей, на содержание микроэлементов и других биогенных веществ в растениях, на устойчивость сельскохозяйственной продукции к хранению, на вкусовые качества и пищевую ценность растений и на здоровье человека.

До $80 \%$ пестицидов адсорбируется почвенным гумусом, поэтому время их пребывания в почве значительно возрастает. В таком состоянии они практически не подвергаются биоразложению. Испаряясь с поверхности почв, пестициды загрязняют атмосферу, при просачивании попадают в грунтовые воды.

ПДК 11 (предельно допустимая концентрация) - это такая концентрация химического вещества (в мг на кг почвы в пахотном слое), которая не должна вызывать прямого или косвенного отрицательного влияния на соприкасающиеся с почвой среды и здоровье человека, а также на способность почвы к самоочищению. Существует 4 разновидности ПДК $_{11}$ в зависимости от путей миграции химических веществ в сопредельные среды:

- TB - транслокацุионный показатель, характеризующий переход вещества из почвы через корневую систему в зеленую массу и плоды растений;

- МА - миграционный воздушный показатель, характеризующий переход химического вещества из почвы в атмосферу;

- MB - миграционный водньй показатель, характеризующий переход химического вещества из почвы в подземные грунтовые воды и водоисточники;

- ОС - общесанитарный показатель, характеризующий влияние химического вещества на способность почвы к самоочищению и на живое население почвы.

При применении новых химических соединений, для которых отсутствует ПДК, проводят расчет временно допустимых концентраций (ВДК 11$)$ по формуле:

$$
\text { ВДК }{ }_{11}=1,23+0,48 \text { ПДК }
$$

где ПДК пр. - предельно допустимая концентрация для продуктов (овощные и плодовые культуры), мг/ кг.

Отбор проб почвы для исследования проводят на участке площадью 25 м $^{2}$ в 3-5 точках по диагонали с глубины 0,25 м, а при выяснении влияния загрязнений на грунтовые воды - с глубины 0,75-2 м. Масса каждой пробы должна составлять 0,2-1 кг.

Классификацию почв по степени загрязнения проводят по предельно допустимым количествам (ПДК) химических веществ и их фоновому загрязнению. По степени загрязнения почвы подразделяются на:

- сильнозагрязненные;

- среднезагрязненные;

- слабозагрязненные.

К сильнозагрязненным относят почвы, в которых содержание загрязняющих веществ в несколько раз превышает ПДК, имеющие низкую биологическую продуктивность, существенное изменение физико-химических, химических и биологических характеристик.

К среднезагрязненным относят почвы, в которых установлено превышение ПДК без существенных изменений в свойствах почв.

К слабозагрязненным относят почвы, в которых содержание химических веществ не превышает ПДК, но выше естественного фона.

Коэффициент концентрации загрязнения почвы $\mathrm{H}_{\mathrm{c}}$ вычисляется по формуле: 


$$
H_{c}=\frac{C}{C_{\phi}} \quad \text { или } \quad H_{c}=\frac{C}{C_{n д \kappa}},
$$

где: C - общее содержание загрязняющих веществ;

$$
\mathrm{C}_{\phi} \quad \text { среднее фоновое содержание }
$$

загрязняющих веществ;

$\mathrm{C}_{\text {пдк }}$ - предельно допустимое содержание загрязняющих веществ.

Очень часто удобрения вносят в почву неочищенными, что является причиной загрязнения почв радиоактивными (например, изотопами калия при использовании калийных удобрений), а также токсическими веществами. Различные формы суперфосфатов, обладая кислой реакцией, способствуют подкислению почвы, что нежелательно для районов, где уровень $\mathrm{pH}$ почвы понижен. Избыточное количество фосфорных удобрений, стекая в стоячие и медленно текущие воды, вызывает развитие большого количества водорослей и другой растительности, что ухудшает кислородный режим водоемов и способствует их зарастанию.

В ряде случаев удобрения перевозятся без надлежащей упаковки, хранятся без укрытий на окраинах полей, где они слеживаются, загрязняются и становятся по внешнему виду весьма схожими между собой. В связи с этим современный эколог должен уметь распознавать удобрения по внешнему виду и простым качественным реакциям. В решении этой задачи, прежде всего, могут помочь лабораторные работы, которые должны проводиться в условиях, максимально приближенным к естественным. В рабочей программе по предмету «Агроэкология» нами предложена лабораторная работа на тему «Качественное распознавание минеральных удобрений как возможных загрязнителей почв и сельхозпродукции».

О загрязнении почвы судят по общему азоту почвы и числу Хлебникова. Если содержание общего азота в конкретном месте возрастает в 2-3 раза, то говорят о загрязнении почвы. О степени загрязнения почвы органическими веществами свидетельствует соотношение азота гумуса (переработанных веществ) ко всему органическому азоту, находящемуся в почве:

число Хлебникова $=$ азот гумуса норма $=$ 0,98-1,0 весь органический азот 1,0 .

Чем чище почва, тем это число ближе к

Большую роль играет влажность почвы. Только в ней передвигаются все химические вещества, происходят химические и биологические процессы, осуществляющие самоочищение почвы и снабжение питанием всего в ней и на ней живущего.
По способу попадания в почву загрязнители делят на 2 группы:

1. вносимые целенаправленно, планомерно - пестициды, удобрения, стимуляторы роста растений и т.д.;

2. попадающие случайно, с техногенными жидкими или твердыми выбросами выхлопные газы автомашин, газы заводов, ТЭЦ и т.Д.

По происхождению они могут быть промышленными (металлы, нефтепродукты), автомобильными (сажа, свинец), сельскохозяйственными (навоз, помет), результатами аварий, испытаний атомных бомб или военных действий (повышенная радиоактивность, применение дефолиантов).

Одна из теорий происхождения ВИЧинфекции: атомные испытания в атолле Бикини - выделение радиоактивной пыли - осаждение ее на почву и растения Центральной Африки поступление в организм питающихся плодами обезьян - мутация природного обезьяннего возбудителя СПИДа - заражение человека (СПИД человеческий).

Существующие вокруг металлургических заводов повышенные выбросы фтора приводят к некрозу листьев у плодовых деревьев, флюорозу, болезням печени, почек, желудочнокишечного тракта у людей и кроветворения у детей; никеля - к учащению заболеваний шизофренией; ртути - заболеваниям эндокринной и нервной систем, мочеполовых органов у мужчин и снижению фертильности у женщин; свинца - расстройству кроветворения, репродуктивной системы и злокачественным новообразованиям.

\section{Conclusion}

Стремление побыстрее и в большем объеме вырастить урожай овощей толкает производителей на повышенное внесение в почву удобрений - нитратов. Для растений нитраты необходимы для построения белка и хлорофилла. Если взрослый человек на суточную дозу нитратов в 200-300 мг на кг веса не реагирует, то у ребенка реакция начинается с 4-5 мг/кг.

Таким образом, загрязнение почвы экзогенными химическими веществами приводит к образованию искусственных техногенных биогеохимических провинций, в которых опосредованно, через контактирующие с почвой среды (питьевую воду, продукты питания, атмосферный воздух), формируется повышенная химическая нагрузка на организм человека, опасная для его здоровья. Чтобы люди имели безопасные в химическом отношении пищевые продукты, питьевую воду, атмосферный воздух и не нарушался процесс 


\begin{tabular}{|c|c|c|c|c|c|c|}
\hline Impact Factor: & $\begin{array}{l}\text { ISRA (India) } \\
\text { ISI (Dubai, UAE } \\
\text { GIF (Australia) } \\
\text { JIF }\end{array}$ & $\begin{array}{l}=1.344 \\
=0.829 \\
=0.564 \\
=1.500\end{array}$ & $\begin{array}{l}\text { SIS (USA) } \\
\text { PИНЦ (Russia) } \\
\text { ESJI (KZ) } \\
\text { SJIF (Morocco) }\end{array}$ & $\begin{array}{l}=0.912 \\
=0.234 \\
=3.860 \\
=\mathbf{2 . 0 3 1}\end{array}$ & $\begin{array}{l}\text { ICV (Poland) } \\
\text { PIF (India) } \\
\text { IBI (India) }\end{array}$ & $\begin{array}{l}=6.630 \\
=1.940 \\
=4.260\end{array}$ \\
\hline
\end{tabular}

самоочищения в почве, необходимо ограничить (регламентировать) поступление химических веществ в почву до определенных концентраций.

Основной нашей целью является формирование у студентов умения вести мониторинг почвенного покрова - одна из составляющих экологического образования, неотъемлемая часть формирования общей экологической культуры. Ведение постоянных наблюдений за изменениями, происходящими в природе, выработает у современной молодежи сознательное и бережное отношение к земле и воде, что, является «не менее важным нравственным императивом, чем бережное отношение к предметам цивилизации. Именно такой подход - одно из необходимых условий, для того чтобы наша республика могла уверенно смотреть в своё будущее, чтобы мы были спокойными за судьбу и благополучие наших детей. Земля, воздух, вода и огонь в нашем регионе почитались издревле, поэтому отношение к земле - это ещё и показатель духовного состояния нашего народа.

\section{References:}

1. Karimov IA (1997) Uzbekistan na poroge XXI veka: ugrozy bezopasnosti, uslovija i garantii progressa. $-\mathrm{T}$..

2. Peter Rillero (2017) «Ecology».

3. Hanhodzhaeva NB, Tursunbaeva GS (2015) Jekologija i ohrana prirody. Uchebnometodicheskoe posobie.- Tashkent.

4. Mizina NG (2012) Gigienicheskaja ocenka riska dlja zdorov'ja detskogo naselenija pri vozdejstvii tjazhelyh metallov, zagrjaznjajushhih okruzhajushhuju sredu: (na primere g. Omska): avtoref. dis. ... k. m. n.Kemerovo. - 22 p.

5. Motuzova GV, Karpova EA (2013) Himicheskoe zagrjaznenie biosfery i ego jekologicheskie posledstvija. - M.: Izd-vo Moskovskogo universiteta.- $304 \mathrm{p}$.

6. Minkina TM, Nevidomskaya DG, Pol'shina TN et al. (2017) J Soils Sediments 17: 1474. doi:10.1007/s11368-016-1381-x

7. Perel'man AI (2015) Geohimija. Izd.3 URSS. 2015. 528 s. ISBN 978-5-9710-2354-8 